\title{
PHOTOCHEMICAL PROCESSES FOR REMOVAL OF CARBAMATE PESTICIDES FROM WATER*
}

Anđelka Tomaševićc ${ }^{4 *}$, Slobodan Petrović², Dušan Mijin ${ }^{2}$

${ }^{1}$ Institute of Pesticides and Environmental Protection, Belgrade-Zemun, Serbia

2University of Belgrade, Faculty of Technology and Metallurgy, Belgrade, Serbia

A large number of pesticide active ingredients have been registered and marketed for pest control purposes around the world. Most pesticides, including carbamates are resistant to chemical and natural photochemical degradation, so that developing adequate methods for remediation of contaminated waters is a priority. There are different methods for removing carbamate pesticide residues from water, and photodegradation methods are discussed in this study. According to literature data, the most beneficial photochemical processes for removal of pesticides from water are two well-known Advanced Oxidation Processes: heterogeneous photocatalysis with semiconductor oxides $\mathrm{TiO}_{2}$ and $\mathrm{ZnO}$, and homogeneous photo-Fenton treatment, as well as direct UV photolysis. Photochemical investigations may contribute toward our better understanding of carbamate pesticide behavior in the environment, i.e. more information on the degradation time of active ingredients, their activity and environmental fate can be obtained by studying the kinetics of any photochemical reaction.
(REVIEW PAPER)

UDC 541.14:628.31:615.285

Keywords: methomyl, carbofuran, photodegradation, photolysis, photocatalysis

\section{Introduction}

Water is an essential compound for life on Earth and its quality is crucial for the future of humanity. The demand for clean water is expected to increase by midcentury, according to [1]. Only a small fraction of the available surface water has the quality necessary for human and industrial use, and improvement of technologies for treatment of wastewater, remediation of polluted water and elimination of micropollutants from water are very important expectations. Removing pesticide residues from water is very difficult and pesticide pollution in surface and groundwater has been recognized many years ago as an important issue in a number of countries. There are two sources of pesticides that contaminate aqueous media: (1) wastewaters from pesticide manufacturing plants, agricultural fields, and equipment rinsing operations and (2) surface water and groundwater. Whereas wastewaters often contain very high level of pesticides (a milligram per liter or more), surface water and groundwater usually contain only trace amounts of pesticides (a microgram per liter or less), but these often occur as a more complex mixture [2].

Carbamates are a large group of pesticides which have been extensively used over the past seventy years primarily as insecticides, but also as herbicides and fungicides. This group includes more than 50 different chemicals which are identified as a group of pesticides with a potential to affect the functioning of the nervous sistem. Due to their widespread use in agriculture and relatively good solubility in water, carbamates represent potential contaminants of both surface and ground water resources [3]. Methomyl and carbofuran (Figure 1) are carbamate pesticides which have been in use for many years. The Environmental Protection Agency, World Health Organization, and European Commission have classified methomyl and carbofuran as highly toxic compounds. Methomyl (IUPAC name: S-methyl $\mathrm{N}$-(methylcarbamoyloxy)thioacetimidate, CAS No.:16752-77-5) is a systemic insecticide and acaricide with contact and abdominal actions. It was first introduced in 1966 by Du Pont Company. Methomyl is used for foliar treatment of vegetables, fruit field crops, cotton, etc. According to [3], methomyl is a hazardous compound, and it is a pollutant of environmental concern because of its high solubility in water $(57.9 \mathrm{~g} / \mathrm{L}$ at $25^{\circ} \mathrm{C}$ ). Additionally, since its sorption affinity to soils is rather low, various amounts of methomyl have been detected in ground and surface waters across Europe and America [4]. The formulation types used for this active ingredient are SL, SP, and WP. Carbofuran (IUPAC name: 2,3-dihydro-2,2-dimethylbenzofuran-7-ylmethylcarbamate, CAS No.:1563-66-2) is a systemic insecticide, acaricide, and nematocide with predominant contact and

\footnotetext{
${ }^{*}$ The paper was presented at 13th Symposium with international participation "NOVEL TECHNOLOGIES AND ECONOMIC DEVELOPMENT" as a plenary lecture, Faculty of Technology in Leskovac,

18-19 October, 2019.

** Author adress: dr Anđelka Tomašević, Institute of Pesticides and Environmental Protection,

Banatska 31b, P.O. Box 163, 11080 Belgrade-Zemun, Serbia

E-mail: Andjelka.Tomasevic@pesting.org.rs

The manuscript received: August, 29, 2019.
} 
abdominal actions. It was introduced in 1965 under the trade name Furadan by FMC Corporation. Carbofuran has relatively good solubility in water $\left(0.35 \mathrm{~g} / \mathrm{L}\right.$ at $\left.25^{\circ} \mathrm{C}\right)$ and a resulting great potential for groundwater and surface water contamination [3,5]. Moreover, it can produce extensive negative effects in aqueous ecosystems [3,6]. This active ingredient is prepared as FS, GR, SC or WP formulation.<smiles>CNC(=O)O/N=C(/C)SC</smiles><smiles>CNC(=O)Oc1cccc2c1OC(C)(C)C2</smiles>

Figure 1. Structure of methomyl (left) and carbofuran (right).

Various processes have been investigated in order to reduce pesticide concentrations in water and to minimize the potential health risks. Conventional wastewater treatments involve mechanical, biological, physical and chemical processes. These methods of water disinfection and decontamination can be a successful solution to a lot of problems caused by pesticide concentrations. However, these methods are often exacting in large systems, in terms of required chemicals, energy and labour, and thus require considerable infusion of capital, engineering expertise and infrastructure, all of which precludes their widespread use around the world. Furthermore, intensive chemical treatments, involving ammonia, chlorine compounds, hydrochloric acid, sodium hydroxide, ozone, permanganate, aluminum and ferric salts, coagulation and filtration aids, anti-scalants, corrosion control chemicals, and ion exchange resins can add to the problems of contamination and salting of freshwater sources. Physical treatments involving coagulation, flocculation, sedimentation, flotation, filtration, adsorption, etc., transfer the pollutants from the liquid phase to a new phase rather than eliminate them. Chemical treatments can also release other hazardous materials into the air or into "purified" water and thus replace the original contamination by different pollutants [7].

Photochemistry is the chemistry of reactions induced by light, and photodegradation occurs as a degradation of photodegradable molecules caused by the absorption of photons, particularly those wavelengths found in sunlight, such as UV, VIS or IR light. Photodegradation includes photodissociation, i.e., the breakup of molecules into smaller pieces by photons. It also includes the change of molecule shape to make it irreversibly altered, such as the denaturation of proteins, as well as the inclusion of different atoms or molecules. A common photodegradation reaction is oxidation and it is used by some drinking water and wastewater facilities to destroy pollutants. Photochemical processes could be used for treatment of many hazardous organic contaminants in water, aqueous waste streams, soils and groundwater, and for decontamination of pathogen water [8].

The aim of this paper is to present several technologies based on photochemical processes for the degradation of the carbamate pesticides, methomyl and carbofuran from water and wastewaters under near-ambient conditions. The most beneficial processes for removal of pesticide residues from water are direct UV photolysis and Advanced Oxidation Processes (AOPs). This presentation focuses on the photolytic and photocatalytic removal of methomyl and carbofuran at low concentration from different types of water, upon the activity of UV, visible or natural solar light, in the presence of $\mathrm{TiO}_{2}$ and $\mathrm{ZnO}$ catalysts, and using Fe-ZSM-5-zeolite and AIFe-pillared montmorillonite. The effects of different operational parameters, such as the initial concentration of pesticides and catalysts, $\mathrm{pH}$, and initial salt concentration were examined. A comparative study on the degradation of carbofuran and its commercial product, Furadan 35-ST, at 315-400 nm in ZnO aqueous suspension will also be presented to evaluate the effects of the inert ingredients, present in the commercial product, on carbofuran photodegradation. The rate of pesticides photodecomposition was measured using UV spectroscopy and high-performance liquid chromatography (HPLC), while their mineralization was investigated by ion chromatography (IC) and total organic carbon analysis (TOC). Photodegradation products of pesticides were identified based on the results of high-performance liquid chromatography-tandem mass spectrometry (HPLC-MS/ MS) and gas chromatography-mass spectrometry (GCMS), and their photodegradation pathways are proposed.

\section{Photolysis}

Photolysis is a direct photodegradation reaction or photodegradation process that involves no catalyst and uses light only for degradation of various molecules such as different environmental contaminants, including pesticide residues. Direct irradiation can promote pesticides into their excited singlet states, which may then cross into the intersystem and produce long-lived triplet states. Such excited states can then undergo homolysis, heterolysis or photoionization processes $[9,10]$. Photolysis takes place in various aqueous and non-aqueous media, such as water (river, deionized, distilled, seawater, tap water, with different ions, with $\mathrm{O}_{2}$ and $\mathrm{O}_{2} / \mathrm{O}_{3}$, etc.), different aqueous solutions and media (buffers solutions, water with ions, methanol/water, chloroform/water, ethanol/ water), different organic solvents ( $i$-propanol, $n$-hexane, methanol, 2-propanol, benzene, acetonitrile, mixtures of the solvents, etc.), and other media (water/soil suspension, thin films, glass, etc.) [9]. Since direct photodegradation by solar light is limited, various lamps were used for irradiation of contaminated water or non-water solutions: low-, medium-, and high-pressure mercury vapor lamps, xenon, fluorescent, mercury-xenon lamps, etc. The kinetics of photolysis reactions in aqueous solution depends on various reaction parameters such as type of light, lamp distance, temperature, initial concentration of pesticides, type of water, $\mathrm{pH}$, the presence of humic and fulvic acids, 
the presence of $\mathrm{O}_{2}, \mathrm{O}_{3}, \mathrm{O}_{2} / \mathrm{O}_{3}$ and $\mathrm{H}_{2} \mathrm{O}_{2}$, the presence of inorganic ions and organic matter dissolved in water, etc. [9,11-13].

The photolysis of $16.22 \mathrm{mg} / \mathrm{L}\left(1 \times 10^{-4} \mathrm{M}\right)$ of methomyl in different types of water (deionized, distilled, and sea water) using an Osram mercury lamp ( $2 \times 8 \mathrm{~W})$ was studied, and the influence of reaction parameters to pesticide degradation was investigated $[11,13,14]$. All experiments were performed under monochromatic $254 \mathrm{~nm}$ ultraviolet light since 366 and 315-400 nm light had no effect on methomyl photolysis, as previously established [13]. The photolytic studies showed that methomyl was effectively decomposed by $254 \mathrm{~nm}$ light in the three types of water (including seawater), and the photolysis rate depended on the lamp distance, water type, reaction temperature, and $\mathrm{pH}$. The reaction rate of methomyl removal decreased with the increase of lamp distance and the reaction rate was 3.7 times higher $\left(k=0.0194 \mathrm{~min}^{-1}\right)$ when the lamp was placed at $20 \mathrm{~mm}$ from the reaction mixture surface in comparison to the reaction $\left(k=0.0053 \mathrm{~min}^{-1}\right)$ when the lamp was placed at $200 \mathrm{~mm}$. Also, the influence of water type on degradation process was assessed in deionized ( $\mathrm{pH}$ 5.2), distilled ( $\mathrm{pH} 5.5)$, and seawater ( $\mathrm{pH}$ 7.9). The results are shown in Table 1: all reactions followed firstorder kinetics and the reaction rate was highest in distilled water and lowest in seawater. The obtained results suggest that certain ions in distilled water promote photolysis of methomyl, while some ions from seawater (such as $\mathrm{Cl}^{-}$, $\mathrm{HCO}_{3}^{-}, \mathrm{SO}_{4}^{2-}$, etc.) decelerated the photolytic process. In addition, it was found that the reaction rate increased in a temperature range from $10^{\circ} \mathrm{C}\left(k=0.0076 \mathrm{~min}^{-1}\right)$ to $50^{\circ} \mathrm{C}$ $\left(k=0.0098 \mathrm{~min}^{-1}\right)$, while half-lives decrease from 91.20 to $70.73 \mathrm{~min}$, respectively. It was also found that reaction rate was highest in neutral $(\mathrm{pH} 6.00)$ and lowest in acidic media ( $\mathrm{pH} 3.15)$ (Figure 2).

Table 1. Kinetics of methomyl photolysis under $254 \mathrm{~nm}[11,13]$

\begin{tabular}{lccc}
\hline Water type & & Parameters & \\
& $k\left(\mathrm{~min}^{-1}\right)$ & $R$ & $t_{1 / 2}(\min )$ \\
\hline Deionized & 0.007 & 0.999 & 97.63 \\
Distilled & 0.009 & 0.999 & 79.67 \\
Sea & 0.006 & 0.994 & 123.78 \\
\hline
\end{tabular}

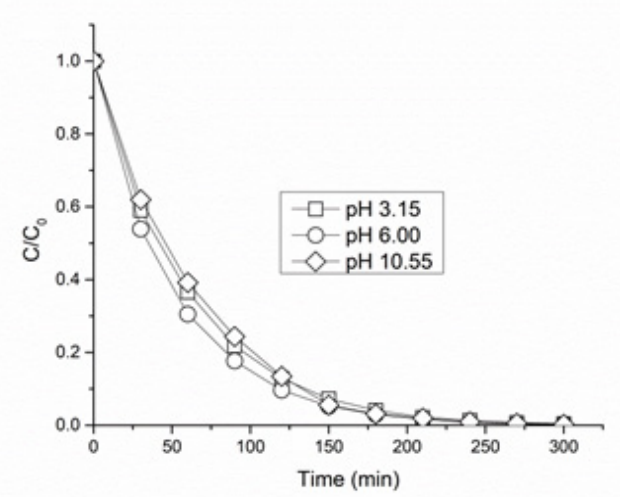

Figure 2. The effect of $\mathrm{pH}$ on the photolysis rate of methomyl (distilled water, lamp distance $100 \mathrm{~mm}$, temperature $20^{\circ} \mathrm{C}$ ).

\section{Advanced Oxidation Processes (AOPs)}

According to [15], complete degradation of organic pollutants, including pesticides and related compounds is not possible by conventional physical, chemical and biological treatments, because they only transfer the contaminants from one phase to another. Advanced Oxidation Processes (AOPs) have great capability in water treatment and purification, including pesticides and other deleterious contaminants. AOPs have been precisely defined as "near ambient temperature and pressure water treatment processes which involve the generation of hydroxyl radical in sufficient quantity to effective water purification" [16]. These processes have recently attracted increasing attention, and there are numerous studies relating to the fundamental and applied aspects of AOPs [5,7-32]. AOPs, which utilize hydroxyl radical, include catalytic and photochemical methods and have $\mathrm{H}_{2} \mathrm{O}_{2}, \mathrm{O}_{3}$ or $\mathrm{O}_{2}$ as the oxidant. AOPs include different processes: ozonation, UV-based processes, sonolysis, radiolysis, photocatalysis, Fenton, photo-Fenton and Fenton like-reactions, electrochemical oxidation, wet air oxidation, ultrasound and microwave processes, as well as all different combinations of the mentioned processes. The principal active species in these systems is the hydroxyl radical $\cdot \mathrm{OH}$, which is a powerful, extremely reactive and non-selective oxidant for most organic contaminants, including aromatic and halogenated compounds, pesticides, halogenated hydrocarbons, etc. $[8,17,18,22,23,33,34]$. Hydroxyl radical has oxidation potential of $\mathrm{E}^{0}=2.73 \mathrm{~V}$ and shows faster rates of oxidation as compared to other conventional oxidant [23,35,36]. Most organic compounds react with ${ }^{\circ} \mathrm{OH}$ by adding or absorbing hydrogen to form a carbon-charged radical. The carbon-charged radical reacts with molecular oxygen to form a peroxyl radical that undergoes subsequent reactions producing oxidation products (ketones, aldehydes, and alcohols) $[9,17,34,37]$. The main advantage of AOPs is the almost complete mineralization of many organic pollutants to water, $\mathrm{CO}_{2}$, mineral salts, and nontoxic compounds $[7,17,32]$.

AOPs involve different homogeneous (when both the catalyst and reactant are in the same phase) and heterogeneous (when the reactant and catalyst are in different phases) photocatalytical processes. Homogeneous photocatalytic oxidation employs various oxidation system (Fenton reagent, $\mathrm{H}_{2} \mathrm{O}_{2}, \mathrm{O}_{3}$, etc.) either alone or in combination with UV, visible, and natural solar light $[17,38]$. Heterogeneous photocatalytical processes, named heterogeneous photocatalysis are a combination of UV or solar light, various catalysts $\left(\mathrm{TiO}_{2}, \mathrm{ZnO}, \mathrm{ZnS}, \mathrm{ZrO}_{2}, \mathrm{CdS}\right.$, $\mathrm{SnO}_{2}, \mathrm{WO}_{3}$, etc.) and different oxidants $\left(\mathrm{H}_{2} \mathrm{O}_{2}, \mathrm{~K}_{2} \mathrm{~S}_{2} \mathrm{O}_{8}\right.$, $\mathrm{KIO}_{4}, \mathrm{KBrO}_{3}$, etc. $)[11,21,24,26]$.

The chemistry of AOPs is very complex due to a variety of reactions involved, and many details on improving the efficiency of photo processes are still unknown. The fundamentals of AOPs include the generation and type of radicals, the fate and type of reactions, the fate of compounds during reactions, etc. Radical reactions in- 
clude three stages: the initial stage of radical generation, the radical reaction stage, and termination stage of radical recombination. There are several different options for radical generation since not only $\bullet \mathrm{OH}$ radicals are generated, but also other radicals may have considerable contributions as parts of chain reactions depending on the conditions of applications and processes $[9,17]$. Consequently, it is not possible to give a comprehensive description of all AOPs, but several currently employed processes have been described.

\section{Heterogeneous photocatalysis}

Photocatalysis is a combination of photochemistry and catalysis, a process where light and catalysis are simultaneously used to promote or accelerate a chemical reaction. Direct light absorption is one of the significant advantages of photocatalysis over thermally active catalytic processes. In comparison with classical treatments photocatalys currently appears to be an excellent method of final treatments of samples containing organic pollutants [39-41]. The main equations of the heterogeneous photocatalysis are $[7,17,42,43]$ :

$$
\begin{aligned}
& \mathrm{C}+h v \rightarrow \mathrm{C}\left(\mathrm{e}^{-}+\mathrm{h}^{+}\right) \cdot \\
& \mathrm{h}^{+}+\mathrm{H}_{2} \mathrm{O} \rightarrow{ }^{\bullet} \mathrm{OH}+\mathrm{H}^{+} \\
& \mathrm{e}^{-}+\mathrm{O}_{2} \rightarrow \mathrm{O}_{2} \cdot \ldots \ldots \ldots \ldots
\end{aligned}
$$

The semiconductor titanium dioxide has been widely used as a photocatalyst for starting a chain of redox reactions during the process of water purification $[7,11,21,26]$. It is the most common semiconductor used on photocatalytical processes because of its high catalytical activity, non-toxicity, chemical and biological stability, water insolubility, etc. [44]. Also, it does not involve mass transfer, it can be carried out under ambient conditions (atmospheric oxygen is used as oxidant), has strong resistance to chemical breakdown and photocorrosion and may lead to complete mineralization of organic carbon into $\mathrm{CO}_{2}$ [7]. $\mathrm{TiO}_{2}$ occurs in three crystals forms: anatase, rutile, and brookite. Degussa P-25 has effectively become a standard [7,45-47]. To perform a heterogeneous photocatalytic reaction activated by light it is necessary to use semiconductors with the adequate "band-gap". $\mathrm{TiO}_{2}$ has a high band-gap, of $3.2 \mathrm{eV}$, being consequently activated only by radiation below 380 (390) nm, i.e., using only $10 \%$ of the sunlight spectrum [7]. The mechanism of catalytic action of $\mathrm{TiO}_{2}$ is well-known $[7,11,17,31,42,44]$. Among the various semiconductors employed, $\mathrm{TiO}_{2}$ photocatalytic reaction has received increasing attention because of its low cost when using sunlight as the source of irradiation [7].

The semiconductor zinc oxide is also frequently used as a catalyst in heterogeneous photocatalytic processes and has good characteristics in degradation and mineralization of organic pollutants [11,24,48,49]. ZnO may have one of three types of crystal structure: hexagonal wurtzite, cubic zinc blende, and cubic rock salt, where wurtzite is the most stable structure [50]. ZnO has a wide band gap (3.2 eV) and due to its low production cost and its electrical and luminescence properties it has been studied as a potential photocatalyst [24,50]. The quantum efficiency of $\mathrm{ZnO}$ is significantly larger than that of $\mathrm{TiO}_{2}$. Thus, the greatest advantage of $\mathrm{ZnO}$ in comparison to $\mathrm{TiO}_{2}$ is that it absorbs over a large fraction of the UV spectrum (i.e. solar spectrum) and according the literature data the corresponding threshold wavelength of $\mathrm{ZnO}$ is $440 \mathrm{~nm}$ [7], relatively to $425 \mathrm{~nm}$ [48], and $\mathrm{ZnO}$ is a more suitable photocatalyst for use under visible light conditions $[51,52]$. In addition, photocatalytic degradation with $\mathrm{ZnO}$ is more effective in acidic than in alkaline media [53] because photodecomposition and photo-corrosion of $\mathrm{ZnO}$ occurs in alkaline media [53,54]. It has been reported that during photocatalytic degradation of the herbicide clopyralid in water, ZnO Merck was a better catalyst than $\mathrm{TiO}_{2}$ P-25 (Evonik) [55]. Also, Evgenidou et al. [56] have reported that $\mathrm{ZnO}$ appeared to be the more efficient catalyst in comparison to $\mathrm{TiO}_{2}$, especially at high concentrations (above $0.2 \mathrm{~g} / \mathrm{L}$ of catalyst). Some of the experimental results have also shown that $\mathrm{ZnO}$ exhibits a higher photocatalytic activity than $\mathrm{TiO}_{2}$, especially when the degradation of industrial effluents occurs at neutral $\mathrm{pH}$ [52]. The mechanism of catalytic action of $\mathrm{ZnO}$ is also well-known [11,48,53,54].

The rate and efficiency of a heterogeneous photocatalytic reaction depends on a number of factors, such as the initial concentration of reactant, initial concentration of catalyst, $\mathrm{pH}$, light intensity and radiant flux, temperature, concentration of oxygen, the presence of scavengers and various ions, etc. [7,11,13,14,24,57,58].

The photocatalytic removal of $16.22 \mathrm{mg} / \mathrm{L}\left(1 \times 10^{-4}\right.$ $\mathrm{M})$ of methomyl aqueous solution under UV/VIS (366 and $315-400 \mathrm{~nm}$ ) and natural solar light was examined in the presence of two well-known semiconductor oxides $\mathrm{TiO}_{2}$ and $\mathrm{ZnO}$, and the influence of reaction conditions (initial concentration of methomyl, catalysts type and concentration, $\mathrm{pH}$, and presence of $\mathrm{Cl}^{-}$ions) was studied $[11,13,14,57,58]$. For photocatalytic methomyl degradation at 366 and $315-400 \mathrm{~nm}$ all experiments were performed using 1.0-3.0 g/L of either $\mathrm{TiO}_{2}$ (Merck Eusolex $\mathrm{T}$, anatase modification) or $\mathrm{ZnO}$ (Merck) and the optimal concentration of catalysts was found to be 2.0 $\mathrm{g} / \mathrm{L}$ under both 366 (Figure 3) and 315-400 nm, and $\mathrm{ZnO}$ was always the better catalyst than $\mathrm{TiO}_{2}$ under the same reaction conditions (Table 2). A pseudo-first-order kinetic model was confirmed on the basis of the LangmuirHinshelwood ( $\mathrm{L}-\mathrm{H})$ mechanism $[13,58]$. In addition, the effect of the initial methomyl concentration on photodegradation was studied and the results obtained are presented in Table 3. The results given in Table 3 show that an increase in initial methomyl concentration leads to a lower photodegradation rate. The photocatalytic removal of methomyl at $366 \mathrm{~nm}$ was studied at three different $\mathrm{pH}$ values (3.5, 5.6 and 9.0), adjusted by the addition of $\mathrm{HCl}$ (3.5) or $\mathrm{NaOH}$ (9.0), where the third $\mathrm{pH}$ value was of a 
pure insecticide solution in deionized water. The results imply that the removal rate was the highest in acidic solution and the lowest in alkaline solution (Figure 4). For the removal of methomyl at $315-400 \mathrm{~nm}$, four different $\mathrm{pH}$ values $(2.0,3.5,5.6$, and 9.0) were examined and the results also imply that the removal rate was the highest in acidic solution and the lowest in alkaline solution [13]. It was also found that for degradation at both 366 and $315-400 \mathrm{~nm}$, the presence of $\mathrm{NaCl}$ led to reaction inhibition due to the scavenging properties of chloride ions $[11,13,14,58]$. The results of the methomyl photocatalytic removal (with 0.1 or $0.2 \mathrm{~g} / \mathrm{L}$ of $\mathrm{TiO}_{2}$ and with $0.15 \mathrm{~g} / \mathrm{L}$ of $\mathrm{ZnO}$ ) under natural sunlight are presented in Table 4. In all cases methomyl dissipation followed the pseudo-first kinetic order. Table 4 shows that $\mathrm{ZnO}$ is the better catalyst for deionized water, while the lower concentration of $\mathrm{TiO}_{2}$ is better for distilled water. In seawater, methomyl disappeared approximately 2 times faster in the presence of $\mathrm{ZnO}$ than in the presence of $\mathrm{TiO}_{2}$. The ion chromatography results confirmed that methomyl mineralization led to the formation of sulfate, nitrate, and ammonium ions (detected in various relative concentrations) during all investigated processes $[11,13,14,58]$.

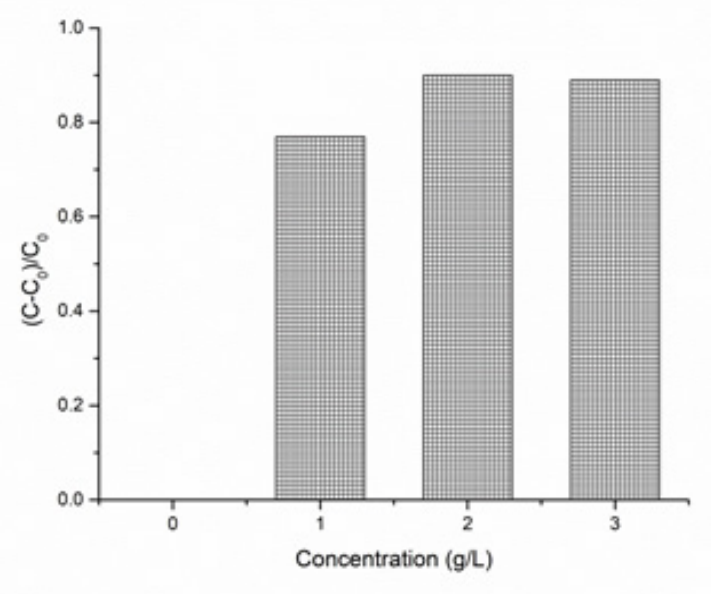

Figure 3. The effect of the $\mathrm{TiO}_{2}$ concentration on the photodegradation efficiency of methomyl at $6 \mathrm{~h}$ irradiation time (methomyl concentration $16.22 \mathrm{mg} / \mathrm{L}$ ).

Table 2. Kinetics of methomyl photodegradation under 315$400 \mathrm{~nm}[11,13,58]$

\begin{tabular}{ccccccc}
\hline Methomyl & \multicolumn{2}{c}{ With $2.0 \mathrm{~g} / \mathrm{L}$ of $\mathrm{TiO}_{2}$} & \multicolumn{3}{c}{ With $2.0 \mathrm{~g} / \mathrm{L}$ of $\mathrm{ZnO}$} \\
& $k\left(\mathrm{~min}^{-1}\right)$ & $R$ & $t_{1 / 2}(\mathrm{~min})$ & $k\left(\mathrm{~min}^{-1}\right)$ & $R$ & $t_{1 / 2}(\mathrm{~min})$ \\
\hline Deionized water & 0.0047 & 0.9941 & 147.48 & 0.0100 & 0.9988 & 69.31 \\
\hline
\end{tabular}

Table 3. Kinetics of methomyl degradation under 315-400 nm in the presence of $2.0 \mathrm{~g} / \mathrm{L}$ of $\mathrm{TiO}_{2}[11,13,58]$

\begin{tabular}{lcccc}
\hline Co $(\mathrm{mg} / \mathrm{L})$ & 16.22 & 12.15 & 8.10 & 4.05 \\
$k\left(\mathrm{~min}^{-1}\right)$ & 0.0047 & 0.0051 & 0.0070 & 0.0077 \\
$1 / k(\mathrm{~min})$ & 212.77 & 196.08 & 142.86 & 129.87 \\
$R$ & 0.9998 & 0.9851 & 0.9771 & 0.9620 \\
\hline
\end{tabular}

Table 4. Kinetics of methomyl photodegradation under natural solar light $[11,13]$

\begin{tabular}{lccccccccc}
\hline Methomyl & \multicolumn{3}{c}{ With $0.1 \mathrm{~g} / \mathrm{L}$ of $\mathrm{TiO}_{2}$} & \multicolumn{3}{c}{ With $0.2 \mathrm{~g} / \mathrm{L}$ of $\mathrm{TiO}_{2}$} & \multicolumn{3}{c}{ With $0.15 \mathrm{~g} / \mathrm{L}$ of $\mathrm{ZnO}$} \\
& $\begin{array}{l}k \\
\end{array}$ & $R$ & $\mathrm{t}_{1 / 2}$ & $k$ & $R$ & $t_{1 / 2}$ & $k$ & $R$ & $\begin{array}{c}t_{1 / 2} \\
\end{array}$ \\
& 0.0018 & 0.9976 & 387.59 & 0.0016 & 0.9955 & 443.85 & 0.0019 & 0.9989 & 364.81 \\
\hline $\begin{array}{l}\text { Deionized } \\
\text { water }\end{array}$ & & & & & & & & & \\
$\begin{array}{l}\text { Distilled water } \\
\text { Sea water }\end{array}$ & 0.0030 & 0.9985 & 228.38 & 0.0022 & 0.9993 & 320.41 & 0.0028 & 0.9975 & 250.53 \\
\hline
\end{tabular}

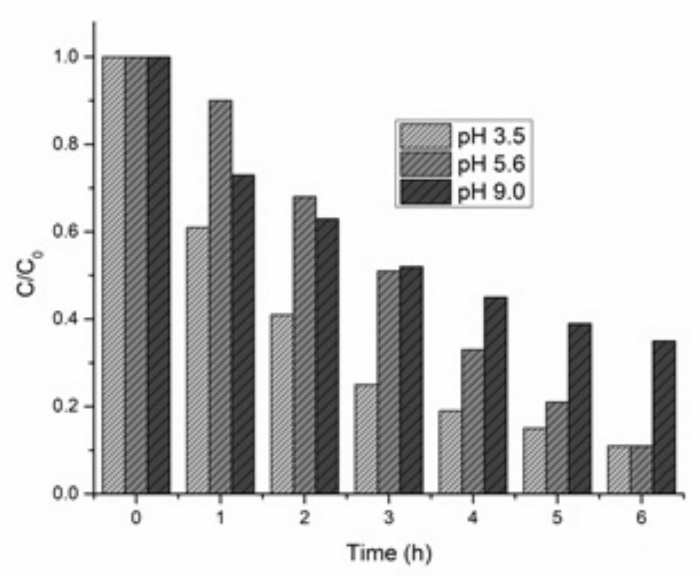

Figure 4. The effect of $\mathrm{pH}$ on the photocatalysis rate of methomyl under $366 \mathrm{~nm}$ (with $2 \mathrm{~g} / \mathrm{L}$ of $\mathrm{TiO}_{2}$, temperature $20^{\circ} \mathrm{C}$ ).

Degradation of $88.4 \mathrm{mg} / \mathrm{L}\left(4 \times 10^{-4} \mathrm{M}\right)$ of carbofuran and its commercial product Furadan 35-ST at 315-400 $\mathrm{nm}$ using $2 \mathrm{~g} / \mathrm{L}$ of $\mathrm{ZnO}$ (Merck) catalyst was studied in order to assess the effects of inert ingredients present in the commercial product on carbofuran photodegradation. In order to be able to apply pesticides in agriculture, it is necessary to prepare them in the forms in which their application is possible. This process is called formulation and it consists of transferring an active pesticide ingredient into a final product. All pesticide formulations are mixtures containing the crucial active ingredient(s) and various other inert ingredients, depending on the formulation type. The inert ingredients may be: antifoam compounds, surfactants, solvents, antifreeze compounds, stability agents, carriers, dyes (occasionally), etc. [59-61]. Hence, the impact of the six inert ingredients present in Furadan 35-ST formulation (Tensiofix CD001, Tensiofix CP002, propylen glycol, polyacrylic acid, xanthan gum, and Rhodamin B) on the adsorption and photodegradation kinetics of carbofuran was examined comparatively. Differences in photodegradation rates were found significant over the first 15 min of degradation, which indicated a detrimental impact of inert ingredients present in the reaction medium containing Furadan 35-ST. Over the period of $15 \mathrm{~min}$, the concentration of carbofuran decreased nearly 10 times, while carbofuran concentration in Furadan 35-ST decreased 2.9 times compared to initial concentration. The $k$ value was higher for carbofuran degradation, $0.1072 \mathrm{~min}^{-1}$, than for Furadan 35ST, $0.0889 \mathrm{~min}^{-1}$ (Table 5). Also, the ion chromatography results confirmed that mineralization of carbofuran and 
Furadan 35-ST led to the formation of acetate, oxalate, and formate ions (detected in various relative concentrations) during the investigated processes (Figure 5), as well as to the formation of methylamine ion, $\mathrm{CH}_{3} \mathrm{NH}_{3}{ }^{+}$ [24]. In addition, GC-MS and HPLC-MS/MS analyses confirmed the formation of three photodegradation products of both carbofuran and Furadan 35-ST: carbofuran phenol, 3-hydroxycarbofuran, 3-ketocarbofuran phenol, and also two Furadan 35-ST degradation products: ion detected at $\mathrm{m} / \mathrm{z} 240$, (TP I), and ion detected at $\mathrm{m} / \mathrm{z} 153$ (TP II). GC-MS analysis revealed the presence of two carbofuran photocatalytic dimerization products: $\mathrm{m} / \mathrm{z}$ 278 and $281\left(t_{R} \approx 16.18\right.$ and $\left.18.05 \mathrm{~min}\right)$. Three degradation products (ions at $\mathrm{m} / \mathrm{z} 153,278$, and 281 ) had not been previously reported [24].

Table 5. Pseudo-first-order rate constants of carbofuran and Furadan 35-ST at different $\mathrm{pH}$ values [24]

\begin{tabular}{|c|c|c|c|c|c|c|c|c|c|c|}
\hline System & C & $\mathrm{F}$ & C & $\mathrm{F}$ & c & $\mathrm{F}$ & C & $\mathrm{F}$ & C & $\mathrm{F}$ \\
\hline $\mathrm{pH}$ & \multicolumn{2}{|c|}{2.7} & \multicolumn{2}{|c|}{3.5} & 5.9 & 6.2 & \multicolumn{2}{|c|}{9.6} & \multicolumn{2}{|c|}{10.2} \\
\hline$k\left(\mathrm{~min}^{-1}\right)$ & 0.1497 & 0.1047 & 0.1302 & 0.0994 & 0.1072 & 0.0889 & 0.0810 & 0.0737 & 0.0724 & 0.0710 \\
\hline$R^{2}$ & 0.9890 & 0.9904 & 0.9654 & 0.9888 & 0.9836 & 0.9638 & 0.9584 & 0.9463 & 0.9786 & 0.9498 \\
\hline
\end{tabular}

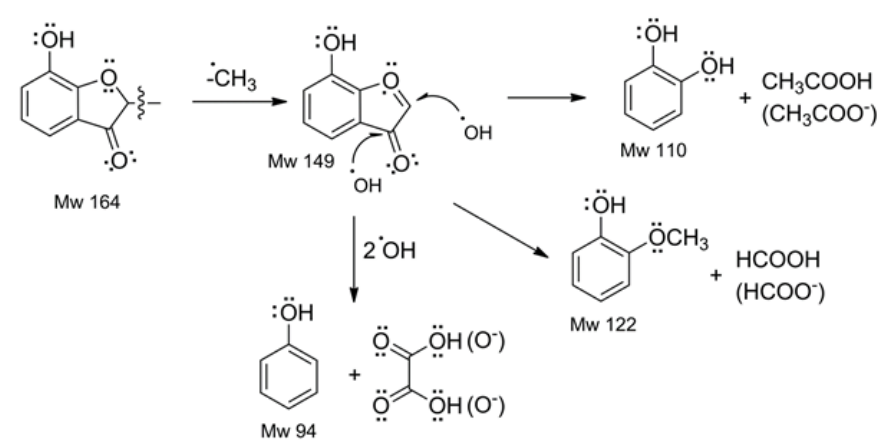

Figure 5. Characteristic fragmentation paths which explain the generation of formate, acetate, and oxalate ions in the course of photocatalytic degradation of carbofuran insecticide.

\section{Photo-Fenton processes}

Fenton and photo-Fenton processes have also received significant attention for water and wastewater treatments [19,62,63]. H.J.H. Fenton discovered in 1894 that several metals have special oxygen transfer properties which improve formation of hydrogen peroxide, i.e. some metals have a strong catalytic power to generate highly reactive hydroxyl radicals [64]. The classic Fenton's reagent is a mixture of ferrous ion and $\mathrm{H}_{2} \mathrm{O}_{2}$ in acidic solution or suspension $[7,19,65,66]$ :

$$
\mathrm{Fe}^{2+}+\mathrm{H}_{2} \mathrm{O}_{2} \rightarrow \mathrm{Fe}^{3+}+\mathrm{OH}^{-+} \cdot \mathrm{OH}^{-}
$$

Equation (4) presents the most important steps of a Fenton reaction and involves electron transfer between $\mathrm{H}_{2} \mathrm{O}_{2}$ and $\mathrm{Fe}^{2+}$ and the resulting production of the highly reactive hydroxyl radical $\bullet \mathrm{OH}$ and potentially reactive $\mathrm{Fe}^{3+}$ species. Degradation of pesticides and other pollutants by Fenton's reagent can be strongly accelerated under UV or various types of visible light, including sunlight. This process is named photo-Fenton reaction $[19,22,34,66-69]$. Equation (4) is the key of photo-Fenton processes. The obtained $\mathrm{Fe}^{3+}$ ion or its $\mathrm{Fe}(\mathrm{OH})^{2+}$ complexes act as light absorbing species, which produce another hydroxyl radical, while the initial $\mathrm{Fe}^{2+}$ ion is regained (equation 5), and the cycle continues [70]:

$\mathrm{Fe}(\mathrm{OH})^{2+}+h v \rightarrow \mathrm{Fe}^{2+}+\cdot \mathrm{OH}^{-}$

The great advantage of the photo-Fenton process, compared with heterogeneous photocatalysis with $\mathrm{TiO}_{2}$ is its sensibility to light up to $600(580) \mathrm{nm}$ [68-70] and the photo-Fenton process allows a more efficient use of sunlight. Disadvantages of the photo-Fenton process include the aggressiveness of treatment due to the low $\mathrm{pH}$ required (usually below 4) and high consumption of $\mathrm{H}_{2} \mathrm{O}_{2}$. Both homogeneous and heterogeneous photo-Fenton processes may be performed. The contact between a pollutant and an oxidizing agent is more effective when the process occurs in homogeneous phase, but the need for removing iron at the end of the process is a disadvantage of its own. In homogeneous photo-Fenton reactions dissolved ferrous sulphate heptahydrate [66,69,71-73] or dissolved ferrous chloride hexahydrate [74] was used as a source of $\mathrm{Fe}^{2+}$ ions. The heterogeneous (when the reactant, products, and catalyst are in different phases) photo-Fenton process uses supported iron catalysts, such as Fe-ZSM-5 zeolite and AlFe-pillared montmorillonite (AIFe-PILC) [5,11,13,14,19,75,76]. These two catalysts have also been used for the destruction of other organic contaminants [77-80]. The kinetics of a photo-Fenton reaction depends on different factors, such as the initial reactant concentration and its characteristics, initial iron concentration and iron source, initial $\mathrm{H}_{2} \mathrm{O}_{2}$ concentration, $\mathrm{pH}$, light intensity, and temperature $[7,11,13,14,19]$.

The catalytic wet peroxide oxidation (heterogeneous photo-Fenton process) of water solution containing $16.22 \mathrm{mg} / \mathrm{L}$ of methomyl under halogen lamp light $(\lambda=$ $575.6 \mathrm{~nm}$ ) in a glass batch reactor under constant air flow, at room temperature and with two types of known iron supported catalysts (Fe-ZSM-5 zeolite and AIFepillared montmorillonite, i.e. AlFe-PILC) was performed $[11,13,14,19,75,76,81]$. The degradation rate of methomyl, and effect of two significant reaction parameters (initial $\mathrm{pH}$ and initial methomyl concentration) were also monitored. Fe-ZSM-5 at concentrations of 1 and $5 \mathrm{~g} / \mathrm{L}$, and AIFe-PILC catalyst at concentrations of 1,3 and $5 \mathrm{~g} / \mathrm{L}$ were used in the experimental study, which showed that methomyl degradation follows the pseudo-first-order reaction kinetics. (Table 6). Both applied catalysts showed a significant activity, but zeolite catalyst was superior. With $5 \mathrm{~g} / \mathrm{L}$ of Fe-ZSM- 5 the reaction was almost entirely completed within the first $30 \mathrm{~min}$, while methomyl degradation with $1 \mathrm{~g} / \mathrm{L}$ of the same catalyst continued for up to $4 \mathrm{~h}$. The degradation of methomyl also proceeded when AIFe-PILC was used as the catalyst, but much more slowly than the reaction with zeolite. The advan- 
tages of zeolite catalyst over pillared clay catalyst include higher activity, good stability (regarding retardation phenomena), and simple separation from the reaction mixture $[78,81]$. Degradation rate was influenced by the initial concentration of methomyl, and a positive effect of $\mathrm{pH}$ value (3.7) was also shown. The IC data showed that only sulfate, nitrate, and ammonium ions, at various concentrations, were formed and identified during degradation. Mineralization of organic carbon, sulfur, and nitrogen from the methomyl molecule was complete and degradation of methomyl practically finished in the first $30 \mathrm{~min}$ when $5 \mathrm{~g} / \mathrm{L}$ of Fe-ZSM-5 zeolite was used, with $100 \%$ of TOC removal. Methomyl degradation under these conditions was extensive, without any intermediate compounds, and led to the formation of $\mathrm{CO}_{2}, \mathrm{H}_{2} \mathrm{O}$ and inorganic ions $\left(\mathrm{SO}_{4}{ }^{2-}, \mathrm{NH}_{4}{ }^{+}\right.$, and $\left.\mathrm{NO}_{3}{ }^{-}\right)$. With $1 \mathrm{~g} / \mathrm{L}$ of Fe-ZSM-5 zeolite, the reaction proceeded much slower than with $5 \mathrm{~g} / \mathrm{L}$ of the same catalyst, and sulfate, nitrate, and ammonium ions, as well as methylamine, were obtained. In this case, mineralization of organic carbon was $80 \%$ within $240 \mathrm{~min}$, and a tentative scheme of methomyl degradation was proposed (Figure 6) [19]. When AlFe-PILC catalyst was used, mineralization of methomyl solution led to the formation of sulfate, nitrate, and ammonium ions, too, but the process was incomplete [19].

Table 6. Pseudo-first-order rate constants of methomyl photodegradation in presence of AIFe-PILC and Fe-ZSM-5 catalysts [19]

\begin{tabular}{lccccc}
\hline Catalyst & AlFe-PILC & AlFe-PILC & AIFe-PILC & Fe-ZSM-5 & Fe-ZSM-5 \\
Concentration $(\mathrm{g} / \mathrm{L})$ & 1 & 3 & 5 & 1 & 5 \\
$k\left(\mathrm{~min}^{-1}\right)$ & 0.0018 & 0.0020 & 0.0025 & 0.0147 & 0.0990 \\
$R^{2}$ & 0.9727 & 0.9636 & 0.9007 & 0.9565 & 0.9045 \\
Time $(\mathrm{h})$ & $0-8$ & $0-8$ & $0-8$ & $0-4$ & $0-0.5$ \\
\hline
\end{tabular}

Figure 6. Tentative pathway for methomyl photocatalytic degradation in the presence of Fe-ZSM-5-zeolite (methomyl concentration $16.22 \mathrm{mg} / \mathrm{L}$, catalyst concentration $1.0 \mathrm{~g} / \mathrm{L}, \mathrm{pH} 3.7$ ).

The heterogeneous photo-Fenton reaction in methomyl and carbofuran water solutions $\left(1.0 \times 10^{-4} \mathrm{M}\right)$ in a glass batch reactor at constant $\mathrm{pH}(3.5-4.0)$, in the presence of AIFe-pillared clay catalyst (PILC) and Fe-ZSM-5 zeolite catalyst (both $5.0 \mathrm{~g} / \mathrm{L}$ ), under halogen lamp light $(575.6 \mathrm{~nm})$ was investigated $[76,82]$. The applied catalysts decomposed methomyl successfully but were inactive for carbofuran degradation. Also, the catalyst testing of carbofuran conversion was carried out at both ambient and elevated $\left(85^{\circ} \mathrm{C}\right)$ temperature. Carbofuran could not be mineralized by the use of AIFe-PILC and Fe-ZSM-5 zeolite catalysts, even in a high-temperature catalytic reaction. The high chemical stability of the carbofuran molecule may be explained by its electronic structure, but this claim requires further theoretical and experimental investigations [76,82].

\section{Conclusion}

Photodegradation processes have been proposed as an effective and attractive techniques for degradation of carbamate pesticides methomyl and carbofuran in water. The kinetics of all photodegradation processes depends on several main parameters, such as the nature of pesticide, type of light, initial concentration of pesticides (and catalysts), $\mathrm{pH}$ of solution, temperature, and presence of an oxidant. The AOPs provide an excellent opportunity to use solar light as an energy source. The photochemical removal of methomyl and carbofuran is an applicable model for purification of water and wastewater.

\section{Acknowledgment}

The authors are grateful to the Ministry of Education, Science, and Technological Development of the Republic of Serbia for funding the study (Projects No. III 46008 and 172013).

\section{References}

[1] UNESCO 2018 The United Nations World Water Development Report 2018: Nature-Based Solution for Water.

[2] D.W. Kolpin, J.E. Barbash, R.J.Gilliom, Occurrence of pesticides in shallow groundwater of the United States: initial results from the National Water-Quality Assessment Program, Environmental Science and Technology 32(5) (1998) 558-566.

[3] C. MacBean (Ed.), The Pesticide Manual, sixteenth ed., BCPC, Alton, Hampshire, 2012.

[4] T.J. Strathmann, A.T. Stone, Reduction of the carbamate pesticides oxamil and methomyl by dissolved Fell and Cul, Environmental Science and Technology 35 (2001) 2461-2469.

[5] A.V. Tomašević, S.M. Gašić, in Advances in Environmental Research, J.A. Daniels Ed., Nova Science Publishers, Inc.,New York 2012, p. 33.

[6] Environmental Protection Agency (EPA) Interim registration eligibility decision carbofuran. D.C. Washington: Prevention, Pesticides and Toxic Substances (7508P), U.S. Environmental Protection Agency, Report 738-R-06-031, USA 2006.

[7] S. Malato, P. Fernandez-lbanez, M.I. Maldonado, J. Blanco, W. Gernjak, Decontamination and disinfection of 
wáter by solar photocatalysis: recent overview and trends, Catalysis Today 147(2-4) (2009) 1-59.

[8] E.E. Kiss, A.V. Tomašević, G.C. Bošković, in Catalysis: Principles, Types and Applications, M. Song Ed., Nova Science Publishers, Inc., New York 2011, p. 307.

[9] H.D. Burrows, M.L. Canle, J.A. Santaballa, S. Steenken, Reaction pathways and mechanisms of photodegradation of pesticides, Journal of Photochemistry and Photobiology B: Biology 67 (2002) 71-108.

[10] T. Katagi, Direct photolysis mechanism of pesticide in water, Journal of Pesticide Science 43(2) (2018) 57-72.

[11] A. Tomašević, D. Mijin, E. Kiss, Photochemical behavior of the insecticide methomyl under different conditions, Separation Science and Technology 45(11) (2010) 16171627.

[12] J. Bachman, H.H. Patterson, Photodecomposition of the carbamate pesticide carbofuran: kinetics and the influence of dissolved organic matter, Environmental Science and Technology 33 (1999) 874-881.

[13] A. Tomašević, Contribution to the studied of the photodegradation mechanism of carbamate pesticides. Thesis, University of Belgrade, Faculty of Technology and Metalurgy, Belgrade, 2011.

[14] A. Tomašević, D. Mijin, E. Kiss, Photochemical behavior of the insecticide methomyl under different conditions, Proceedings of 2nd European Conference on Environmental Application of Advanced Oxidation Processes, Nicosia, Cyprus (2009) 1-6.

[15] S. Devipriya, S. Yesodharan, Photocatalytic degradation of pesticide contaminants in water, Solar Energy Materials and Solar Cells 86 (2005) 309-348.

[16] W.H. Glaze, J.W. Kang, D.H. Chapin, The chemistry of water treatment processes involving ozone, hydrogen peroxide and ultraviolet radiation, Ozone: Science and Engineering 9 (1987) 335-352.

[17] O. Legrini, E. Oliveros, A.M. Braun, Photochemical processes for water treatment, Chemical Reviews 93(2) (1993) 671-698.

[18] P.J. Huston, J.J. Pignatello, Degradation of selected pesticide active ingredients and commercial formulations in water by the photo-assisted Fenton reaction, Water Research 33(5) (1999) 1238-1246.

[19] A. Tomašević, E. Kiss, S. Petrović, D. Mijin, Study on the photocatalytic degradation of insecticide methomyl in water, Desalination 262 (2010) 228-234.

[20] K. Ikehata, M. Gamal El-Din, Aqueous pesticide degradation by hydrogen peroxide/ultraviolet irradiation and Fenton-type advanced oxidation processes: a review, Journal of Environmental Engineering \& Science 5 (2006) 81-135.

[21] A.V. Tomašević, M.L. Avramov-Ivić, S.D. Petrović, M.B. Jovanović, D.Ž. Mijin, A study of the electrochemical behaviour of methomyl on a gold electrode in a neutral electrolyte, Journal of the Serbian Chemical Society 74(5) (2009) 573-579.

[22] M.A. Oturan, J.J. Aaron, Advanced oxidation processes in a water/wastewater treatment: principles and applications. A review, Critical Reviews in Environmental Science and Technology 44 (2014) 2577-2641.

[23] A. Buthiyappan, A.R.A. Aziz, W.M.W. Daud, Degradation performance and cost impication of UV-integrated advanced oxidation processes for wastewater treatments, Review in Chemical Engineering 31(3) (2015) 263-302.

[24] A. Tomašević, D. Mijin, A. Marinković, M. Radišić, N.
Prlainović, R. Đurović-Pejčev, S. Gašić, The photocatalytic degradation of carbofuran and Furadan 35-ST: the influence of inert ingredients, Environmental Science and Pollution Research 24 (2017) 13808-13822.

[25] T. Csay, R. Homlok, E. Illes, E. Takacs, L. Wojnarovits, The chemical background of advanced oxidation processes, Israel Journal of Chemistry 54 (2014) 233-241.

[26] A. M. Dugandžić, A.V. Tomašević, M.M. Radišić, N.Ž.Šekuljica, D.Ž. Mijin, S.D. Petrović, Effect of inorganic ions, photosensitisers and scavengers on the photocatalytic degradation of nicosulfuron, Journal of Photochemistry and Photobiology A: Chemistry 336 (2017) 146-155.

[27] S.S.C. Aiyer, R.S. Thirumavalavan, B.G.P. Kumar, A review of solar photocatalytic degradation of wastewater using advanced oxidation processes, Journal of Industrial Pollution Control 31(2) (2015) 297-309.

[28] M. Bartolomeu, M.G.P.M.S. Neves, M.A.F. Faustino, A. Almeida, Wastewater chemical contaminants: remediation by advanced oxidation processes, Photochemical \& Photobiological Sciences 17 (2018) 1573-1598.

[29] Y. Deng, R. Zhao, Advanced oxidation processes (AOPs) in wastewater treatment, Current Pollution Reports 1 (2015) 167-176.

[30] D.B. Miklos, C. Remy, M. Jekel, K.L. Linden, J.E. Dreves, Evaluation of advanced oxidation processes for water and wastewater treatment - A critical review, Water Research 139 (2018) 118-131.

[31] S.N. Ahmed, W. Haider, Heterogeneous photocatalysis and its potential applications in water and wastewater treatment: a review, Nanotechnology 29(34) (2018) 342001. doi.org/10.1088/1361-6528/aac6ea.

[32] O.M.S. Filipe, N. Mota, S.A.O. Santos, M.R.M. Domingues, A.J.D. Silvestre, M.G.P.M.S. Neves, M.M.Q. Simoes, E.B.H. Santos, Identification and characterization of photodegradation products of metoprolol in the presence of natural fulvic acid by HPLC-UV-MSn, Journal of Hazardous Materials 323 (2017) 250-263.

[33] S. Esplugas, J. Gimenez, S. Contreras, E. Pascual, M. Rodriguez, Comparison of different advanced oxidation processes for phenol degradation, Water Research 36(4) (2002) 1034-1042.

[34] Y. Sun, J.J. Pignatello, Photochemical reactions involved in the total mineralization of $2,4-\mathrm{D}$ by $\mathrm{Fe}_{3}+/ \mathrm{H}_{2} \mathrm{O} / \mathrm{UV}$, Environmental Science and Technology 27 (1993) 304310.

[35] E.J. Rosenfeldt, K.G. Linden, S. Canonica, U. von Gunten, Comparison of the efficiency of $\cdot \mathrm{OH}$ radical formation during ozonation and the advanced oxidation processes $\mathrm{O}_{3} / \mathrm{H}_{2} \mathrm{O}_{2}$ and $\mathrm{UV} / \mathrm{H}_{2} \mathrm{O}_{2}$, Water Research 40 (2006) 36953704.

[36] H. Zhang, H.J. Choi, C.P. Huang, Optimization of Fenton process for the treatment of landfill leachale, Journal of Hazardous Materials 125 (2005) 166-174.

[37] W.J. Cooper, C.J. Cramer, N.H. Martin, S.P. Mezyk, K.E. O,Shea, C. von Sonntag, Free radical mechanisms for the treatment of methyl tert-butyl ether (MTBE) via advanced oxidation/reductive processes in aqueous solutions, Chemical Reviews 109 (2009) 1302-1345.

[38] P. Bautista, A.F. Mohedano, J.A. Casas, J.A. Zazo, J.A. Rodriguez, An overview of the application of Fenton oxidation to industrial wastewater treatment, Journal of Chemical Technology and Biotehnology 83(10) (2008) 1323-1338. 
[39] T.E. Doll, F.H. Frimmel, Removal of selected persistent organic pollutants by heterogeneous photocatalysis in water, Catalysis Today 101 (2005) 195-202.

[40] M. Hincapie, M.I. Maldonado, I. Oller, W. Gernjak, J.A. Sanchez-Perez, M.M. Balestros, S. Malato, Solar photocatalytic degradation and detoxification of EU priority substances, Catalysis Today 101 (2005) 203-210.

[41] S. Dong, J. Feng, M. Fan, Y. Pi, L. Hu, X. Han, M. Liu, J. Sun, Recent developments in heterogeneous photocatalytic water treatment using visible lightresponsive photocatalysts: a review, RSC Advances, 5(19) (2015) 14610-14630.

[42] N. Daneshvar, D. Salari, A.R. Khataee, Photocatalytic degradation of azo dye Acid red 14 in water: investigation of the effect of operational parameters, Journal of Photochemistry and Photobiology A: Chemistry 157(1) (2003) 111-116.

[43] M. Karkmaz, E. Puzenat, C. Guillard, J.M. Herrmann, Photocatalytic degradation of the alimentary azo dye Amaranth. Mineralization of the azo group to nitrogen, Applied Catalysis B: Environmental 51(3) (2004) 183-194.

[44] I.K. Konstantinou, T.A. Albanis, Photocatalytic transformation of pesticides in aqueous titanium dioxide suspensions using artificial and solar light: Intermediates and degradation pathways, Applied Catalysis B: Environmental 42 (2003) 319-335.

[45] M. Muneer, D. Bahnemann, Semiconductor-mediated photocatalyzed degradation of two selected pesticides derivatives, terbacil and 2,4,5-tribromimidazole, in aqueous suspension, Applied Catalysis B: Environmental 36 (2002) 95-111.

[46] D.C. Hurum, K.A. Gray, T. Rajh, M.C. Thurnauer, Recombination pathways in Deguss P25 formulation of $\mathrm{TiO}_{2}$ : Surface versus lattice mechanisms, Journal of Physical Chemistry. Part B 109 (2005) 977-980.

[47] N. Serpone, G. Suave, R. Koch, H. Tahiri, P. Pichat, P. Piccini, E. Pelizzetti, H. Hidaka, Standardization protocol of process efficiences and activation parameters in heterogeneous photocatalysis: Relative photonic efficiences, Journal of Photochemistry and Photobiology A: Chemistry 94 (1996) 191-203.

[48] M.A. Behnajady, N. Modirshahla, R. Hamzavi, Kinetic study on photocatalytic degradation of C.I. Acid Yellow 23 by $\mathrm{ZnO}$ photocatalyst, Journal of Hazardous Materials $\mathrm{B}$ 133(1-3) (2006) 226-232.

[49] B. Pare, S.B. Jonnalagadda, H. Tomar, P. Singh, V.W. Bhagwat, $\mathrm{ZnO}$ assisted photocatalytic degradation of acridine orange in aqueous solution using visible light, Desalination 232 (2008) 80-90.

[50] S.H.S. Chan, T.Y. Wu, J. C. Juan, C.Y. The, Recent developments of metal oxide semiconductors as photocatalysts in advanced oxidation processes (AOPs) for treatment of dye waste-water, Journal of Chemical Technology and Biotechnology 86 (2011) 1130-1158.

[51] M.A. Behnajady, S.G. Moghaddam, N. Modirshahla, M. Shorki, Investigation of the effect of heat attachment method parameters at photocatalytic activity of immobilized ZnO nanoparticles on glass plate, Desalination 249 (2009) 1371-1376.

[52] X. Chen, Y. He, Q. Zhang, L. Li, D.Hu, T. Yin, Fabrication of sandwich-structured $\mathrm{ZnO} /$ reduced graphite oxide composite and its photocatalytic properties, Journal of Materials Science 45 (2010) 953-960.

[53] N. Daneshvar, D.Salari, A.R. Khataee, Photocatalytic degradation of azo dye Acid red 14 in water on $\mathrm{ZnO}$ as an alternative catalyst to $\mathrm{TiO}_{2}$, Journal of Photochemistry and Photobiology A: Chemistry 162 (2004) 317-322.

[54] N. Daneshvar, S. Aber, M.S. Seyed Dorraji, A.R.M. Khataee, H. Rasuolifard, Photocatalytic degradation of the insecticide diazinon in the presence of prepared nanocrystaline $\mathrm{ZnO}$ powders under irradiation of UV-C light, Separation and Purification Technology 58 (2007) 91-98.

[55] C. Berberidou, V. Kitsiou, S. Karahanidou, D.A. Lambropoulou, A. Kouras, C.I. Kosma, T.A. Albanis, I. Poulios, Photocatalytic degradation of the herbicide clopyralid: Kinetics, degradation pathways and ecotoxicity evaluation, Journal of Chemical Technology and Biotechnology 91 (2016) 2510-2518.

[56] E. Evgenidou, K. Fytianos, I. Poulios, Semiconductorsensitized photodegradation of dichlorvos in water using $\mathrm{TiO}_{2}$ and $\mathrm{ZnO}$ as catalysts, Applied Catalysis $\mathrm{B}$ : Environmental 59(2005) 81-89.

[57] A. Tomašević, J. Đaja, S. Petrović, E.E. Kiss, D. Mijin, A study of the photocatalytic degradation of methomyl by UV light, Chemical Industry \& Chemical Engineering Quarterly 15(1) (2009) 17-19.

[58] A. Tomašević, D. Mijin, S. Gašić. E. Kiss, The influence of polychromatic light on methomyl degradation in $\mathrm{TiO}_{2}$ and $\mathrm{ZnO}$ aqueous suspension, Desalination and Water Treatment 52 (2014) 4342-4349.

[59] A. Knowles, New developments in crop protection product formulation. T \& F Informa, Agrow Reports, London 2005.

[60] A. Knowles, Recent developments of safer formulations of agrochemicals, The Environment 28 (2008) 35-44.

[61] A.V. Tomašević, S.M. Gašić, in Insecticides - Basic and Other Applications, S. Soloneski, M. Larramendy Eds., Intech, Rijeka 2012, p. 39.

[62] Z. Wang, C. Chen, W. Ma, J. Zhao, Photochemical coupling of iron redox reactions and transformation of dissolved organic matter (DOM), Journal of Physical Chemistry Letter 3 (2012) 2044-2051.

[63] C.Y. Sun, C.C. Chen, W.H. Ma, J.C. Zhao, Photodegradation of organic pollutants catalyzed by iron species under visible lingt irradiation, Physical Chemistry Chemical Physics 13 (2011) 1957-1969.

[64] H.J.H. Fenton, Oxidation of tartaric acid in presence of iron, Journal of Chemical Society 65 (1894) 899-910.

[65] E. Neyens, J. Baeyens, A review of classic Fenton's peroxidation as an advanced oxidation technique, Journal of Hazardous Materials B 98 (2003) 33-50.

[66] M. Tamimi, S. Qourzal, N. Barka, A. Assabbane, Y. AitIchou, Methomyl degradation in aqueous solutions by Fenton's reagent and the photo-Fenton system, Separation and Purification Technology 61(1) (2008) 103108.

[67] R.G. Zepp, B.C. Faust, J. Hoigne, Hydroxyl radical formation in aqueous reactions $(\mathrm{pH} \mathrm{3-8)}$ in iron(II) with hydrogen peroxide: The photo-Fenton reaction, Environmental Science and Technology 26(2) (1992) 313319.

[68] S. Malato, J. Blanco, A. Vidal, C. Richter, Photocatalysis with solar energy at a pilot-plant scale: an Overview, Applied Catalysis B: Environmental 37 (2002) 1-15.

[69] S. Malato, J. Blanco, J. Caceres, A.R. Fernandez-Alba, A. Agüera, A. Rodriguez, Photocatalytic treatment of watersoluble pesticides by photo-Fenton and $\mathrm{TiO}_{2}$ using solar energy, Catalysis Today 76(2-4) (2002) 209-220. 
[70] M. Rodriguez, S. Malato, C. Pulgarin, S. Contreras, D. Curco, J. Gimenez, S. Esplugas, Optimizing the solar photo-Fenton process in the treatment of contaminated water. Determination of intrinsic kinetic constants for scale-up, SolarEnergy 79(4) (2005) 360-368.

[71] I. Oller, W. Gernjak, M.I. Maldonado, L.A. Perez-Estrada, J.A. Sanchez-Perez, S. Malato, Solar photocatalytic degradation of some hazardous water-soluble pesticides in pilot-plant scale, Journal of Hazardous Materials B 138 (2006) 507-517.

[72] S. Malato, J. Blanco, A. Vidal, D. Alarcon, M.I. Maldonado, J. Caceres, W. Gernjak, Applied studies in solar photocatalytic detoxification: an Overview, Solar Energy 75(4) (2003) 329-336.

[73] A.R. Fernandez-Alba, D. Hernando, A. Aguera, J. Caceres, S. Malato, Toxicity assays: a way for evaluating AOPs efficiency, Water Research 36 (2002) 4255-4262.

[74] M.P. Ormad, R. Mosteo, C. Ibarc, J.L. Ovelleiro, Multivariate approach to the photo-Fenton process applied to the degradation of winery wastewaters, Applied Catalysis B: Environmental 66 (2006) 58-63.

[75] A. Tomašević, G. Bošković, D. Mijin, E.E.Kiss, Decomposition of methomyl over supported iron catalysts, Reaction Kinetics and Catalysis Letters 91(1) (2007) 5359.

[76] A. Tomašević, G. Bošković, D. Mijin, E.E.Kiss, Degradation of carbamates over AlFe-PILC catalyst, Proceedings of PSU-UNS International Conference of Engineering and
Environment, ICEE-2007 and PEC-5, Phuket, Thailand (2007) 124-127.

[77] E.V. Kuznetsova, E.N. Savinov, L.A. Vostrikova, V.N. Parmon, Heterogeneous catalysis in the Fentontype system FeZSM-5/ $\mathrm{H}_{2} \mathrm{O}_{2}$, Applied Catalysis B: Environmental 51(2004) 1165-170.

[78] E.E.Kiss, J.G. Ranogajec, R.P. Marinković-Nedučin, T.J. Vulić, Catalytic wet peroxide-oxidation of phenol over AlFe-pillared montmorillonite, Reaction Kinetics and Catalysis Letters 80 (2003) 255-260.

[79] E.E. Kiss, M.M. Lazić, G.C. Bošković, AlFe-pillared clay catalyst for phenol oxidation in aqueous solution, Reaction Kinetics and Catalysis Letters 83 (2004) 221-227.

[80] M. Bobu, A. Yediler, I. Siminiceanu, S. Schulte-Hostede, Degradation studies of ciprofloxacin on a pillared iron catalyst, Applied Catalysis B: Environmental 83 (2008) 15-23.

[81] K. Lazar, A. Tomašević, G. Bošković, E. Kiss, Comparison of Fe-Al PILC and Fe-ZSM-5 catalysts used for degradation of methomyl, Hyperfine Interactions 192(1-3) (2009) 23-29.

[82] A.V. Tomašević, G.C.Bošković, D.Ž.Mijin, S.M. Đilas, E.E. Kiss, The extremely high stability of carbofuran pesticide in acidic media, Acta Periodica Technologica 38 (2007) 97-103.

\section{Izvod \\ FOTOHEMIJSKI PROCESI ZA UKLANJANJE KARBAMATNIH PESTICIDA IZ VODE}

\section{Anđelka Tomašević ${ }^{1}$, Slobodan Petrović ${ }^{2}$ Dušan Mijin ${ }^{2}$}

1 Institut za pesticide i zaštitu životne sredine, Beograd-Zemun, Srbija

2Univerzitet u Beogradu, Tehnološko-metalurški fakultet, Beograd, Srbija

U cilju zaštite bilja u svetu je registrovan i u prometu se nalazi veliki broj aktivnih materija pesticida. Većina pesticida, uključujući karbamate je otporna na hemijske i prirodne fotohemijske degradacije i zato je prioritet razvijanje odgovarajućih metoda za prečišćavanje zagađenih voda. Postoje različite metode za odstranjivanje ostataka karbamatnih pesticide iz vode a u ovom radu su razmatrane fotodegradacione metode. Prema literaturnim podacima najkorisniji fotohemijski procesi za uklanjanje pesticide iz vode su dva dobro poznata Viša oksidaciona procesa: heterogena fotokataliza u prisustvu poluprovodnih oksida $\mathrm{TiO}_{2}$ i $\mathrm{ZnO}$, i homogeni foto-Fenton postupak, isto kao i direktna ultraljubičasta fotoliza. Fotohemijska istraživanja doprinose boljem razumevanju ponašanja karbamatnih pesticida u životnoj sredini i puno informacija o vremenu degradacije aktivnih materija, njihovoj aktivnosti i sudbini u životnoj sredini može se dobiti proučavanjem kinetike svake fotohemijske reakcije.
(PREGLEDNI RAD)

UDK 541.14:628.31:615.285

Ključne reči: metomil, karbofuran, fotodegradacija, fotoliza, fotokataliza 